\title{
Sustainability of stone materials in the built environment of rural regions: a review
}

\author{
SANJURJO-SÁNCHEZ, J. ${ }^{1}$, ALVES, C., ${ }^{2 *}$ \\ (1) University Institute of Geology "Isidro Parga Pondal", University of A Coruña, Spain \\ (2) LandS/Lab2PT (UID/AUR/04509/2013; POCI-01-0145-FEDER-007528) and School of Sciences, \\ University of Minho, Portugal \\ E-mail: casaix@dct.uminho.pt \\ Telf.: 00351253604300 \\ * Corresponding author
}

https://doi.org/10.17979/cadlaxe.2017.39.0.3556

\begin{abstract}
Stones has been used from pre-historical times with different purposes and this historical use can be seen as an extended record of its sustainability, regarding extraction procedures and consequences, uses in building and maintenance to overcome decay. We discuss in this paper conceptual considerations on the sustainability of local use of rocks in a small scale (what will be assumed to define a "rural" scope), covering both in situ uses, mostly as cave housing, and extracted materials for creation of structures. Our discussion will develop around two main axes: resources consumption (including the rocks themselves and rock wastes resulting from other activities) and pollution impacts (on the surrounding environment and in the users of the rock structures). It will be seen that the main concerns will be related to specific spots with enhanced environmental or cultural value (where small changes can have enormous impacts). Other issues have minimal impact or can be dealt by design options. We consider also possible positive impacts resulting from the use of rock materials, namely in the social and economic components, including the use of rock wastes as resources and the touristic potential of rock quarries, structures and human-made landscapes.
\end{abstract}

Keywords: geological materials; built environment; resources; pollution 


\section{INTRODUCTION}

Stones has been used from pre-historical times, either by works made in situ, directly on rock masses, including housing and artistic works, as shown in Petra and old and modern examples of natural and excavated cave housing (see e.g. Golany 1990; Barbero-Barrera et al 2014) or by being extracted and used as stone blocks in human made elements. Hence, there is an extended record of their sustainable use, with low consumption of resources for longstanding performance (it might be argued that the Easter Island presents the opposite example but see discussion in Deutsch 2012; we will also consider this case in the final considerations). However, rocks are not just an historical material. Berge (1992) quotes a 1983 publication by Shadmon presenting stone as "the building material of the future" due to resources that are "limitless and evenly spread over the whole globe", whose extraction "does not require a lot of energy and does not pollute" and highlighting ("above all") its durability.

Global balances on sustainability issues regarding rock materials are not common but a general, brief, review of stone in the perspective of green buildings, defending the choice of local stone with minimum processing, can be found in Kumar (2015). Another favourable review is presented by SFGB (2011). Here will be discussed conceptual considerations regarding relatively small works using local rocks in rural regions, i.e., rocks used in place or in places very nearby (an advantageous situation in terms of sustainability - see Morel et al. 2001). However, there might be reasons for importing certain kinds of rocks (see next sections). Sustainability assessments should also include, be- yond environmental impacts, economic and social dimensions, from extraction of raw materials to disposal (the classical "cradle to grave") in order to define Life Cycle Sustainability Assessments (Finkbeiner 2010).

In a previous publication (Alves and Sanjurjo-Sánchez 2015) were discussed the major issues of sustainability associated with stone conservation and maintenance. In this paper will be discussed conceptual considerations regarding relatively small works in rural regions that are based on local rocks i.e., rocks used in place or in places very nearby (an advantageous situation in terms of sustainability-see discussion in Morel et al. 2001). However, as it will be shown, there might be reasons for importing certain kinds of rocks.

We will consider rock materials in a very wide sense including hard rocks suitable for use as stone (Figure 1a) as well as softer products that define lithological units or that are derived from hard rocks by alteration (Figure 1b), used as bulk material. Rocks are classically defined as aggregates of minerals and, hence, "Such unconsolidated materials as sand, gravel, clay, soil are justly included among rocks" (Smith Flett 1911). In this perspective, rocks will include stone and part of what Berge (1992) refers as "loose materials". This definition will also include water-soluble evaporites like gypsum that might present particular properties but that is seldom used raw beyond some examples of statuary (gypsum alabaster). However, it will be unusual to include among rock materials the upper organic rich portions of soils associated with vegetation. We will not shy away from references to earth-like materials that can be considered lithological units such as loess or clays, or those that are derived from hard rocks by weathering, but 
sustainability issues of earth materials have been extensively discussed (just to mention books on earth materials, see Minke 2006 and Schroeder 2016). We will not consider materials resulting from intense transformation of rock raw materials such as binders, rock wool, etc.

We expect to present convincing qualitative arguments regarding the main sustainability questions that can be raised in relation to using rocks in rural regions. A key point in our analysis will be whether a given impact is significant, for which, following classical environmental impact assessment (e.g., Canter 1996), will be considered context and

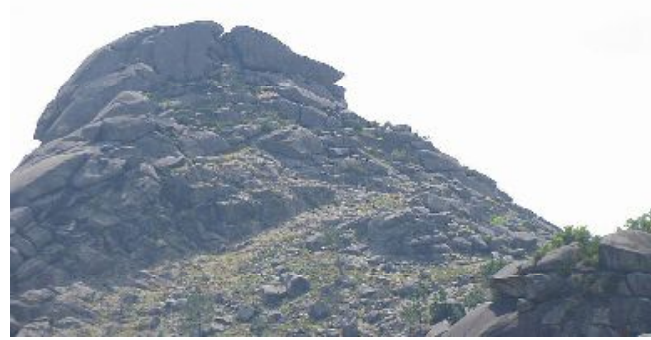

intensity (which is related to the operation size). Most of the images presented here are from places in towns but the illustrated features are, nonetheless, representative of the considered processes on rural regions. Several images are from Braga, a town in NW Portugal, where, however, one can find places or even areas that can be considered representative of rural situations, in the sense of low density of human structures, as will be seen in the presented images. Most of the presented images are from granite rocks (where the experience of the authors lies mostly) but the discussion presented can be applied to all kind of rocks.

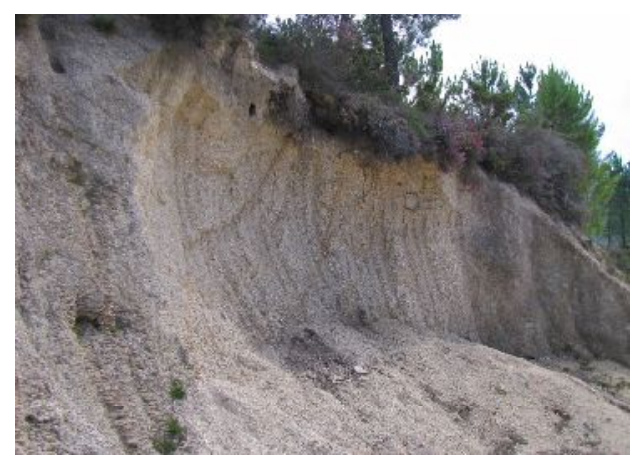

Fig. 1. Examples of products considered in this review in the natural environment (both examples from Terras de Bouro in Northern Portugal): left picture granite dome and blocks (suitable for stone extraction) in northern Portugal; right picture saprolite resulting from granite weathering (Northern Portugal).

The discussion will be more focused on an Earth Sciences perspective (natural sciences) than in a Life Cycle Assessment (or and will be around three lines that define the following sections: resource consumption, pollution impact and other social impacts (in this way we are nearer the perspective of Berge 1992).

\section{RESOURCE CONSUMPTION}

This section will be organised around three lines regarding: (i) rocks resources; (ii) energy; (iii) other natural resources. A first sustainability objection that can be raised against using rocks is that they are, generally, non-renewable materials (some 
sedimentary, quimiogenic and detritic, and some volcanic, lavic and pyroclastic, rocks could be considered an exception to this but they will be laden with unpredictability, especially in the volcanic cases). However, the non-renewable character of rocks can be balanced by three factors: availability, durability and reusability/recyclability.

In terms of availability, it will be trivial to say that stone is an abundant material in areas, where rocks "outcrop" in large amounts. In some rural regions the amount of available rock in relation to that necessary for structures can be so high that make rock resources, in practice, infinite (as referred in the Shadmon quote above). Cave housing could be a more complex situation, raising the question of managing the better spots for excavation and existing natural caves (an assessment of the potential impact on other species that use the caves should be included). The distinction between loose stone and quarry stone (e.g. Berge 1992) can be relevant, since using the best loose stones restricts their availability for future works (this might be lessened by stone reusability potential).

We will like to highlight two further points. Firstly, rocky regions (e.g. Figure 1a) can be little amenable to tree cultivation (plants can grow in rock fractures but for tree production a rock substrate is not favourable and in some regions there are thin, poorly developed or immature soils) and, hence, the promotion of alternatives like timber might have a bigger impact due to land alterations. Secondly, in some regions rocks are an obstacle to land use, either for engineering (see Figure 2) or agricultural works. Therefore, these activities produce rock wastes that need to be reuse or recycle (see review in Magnusson et al. 2015). Of course, excavated housing and stone processing also produces rocky wastes that can/ should be reused/recycled (see next section).

In terms of durability, stone is subject to diverse alteration processes after its emplacement (see Sanjurjo-Sánchez and Alves 2012). Some of them are limited to the surface (stains or coatings). Others imply mass loss, with a depth generally of some millimetres but that sometimes can achieve some centimeters. It is essential, however, to sharply distinguish between visual degradation and degradation that affects the structural function of materials, which in general is not compromised by these alteration processes, excepting some situations associated with fractures. Therefore, stone can be considered a very durable material (possibly the most durable one among the commonest) as it is shown by the persistence of historical structures. Stone is also very durable against factors such as running water, floods, biological colonization, that affect materials such as earth or timber. Usually rocky materials are not flammable and do not require organic strengtheners that might be flammable or subject to rot (problems that affect some variants of earth materials-see Minke 2006) but they can be affected by extreme situations such as fire (Gomez-Heras et al. 2009) or earthquakes. 


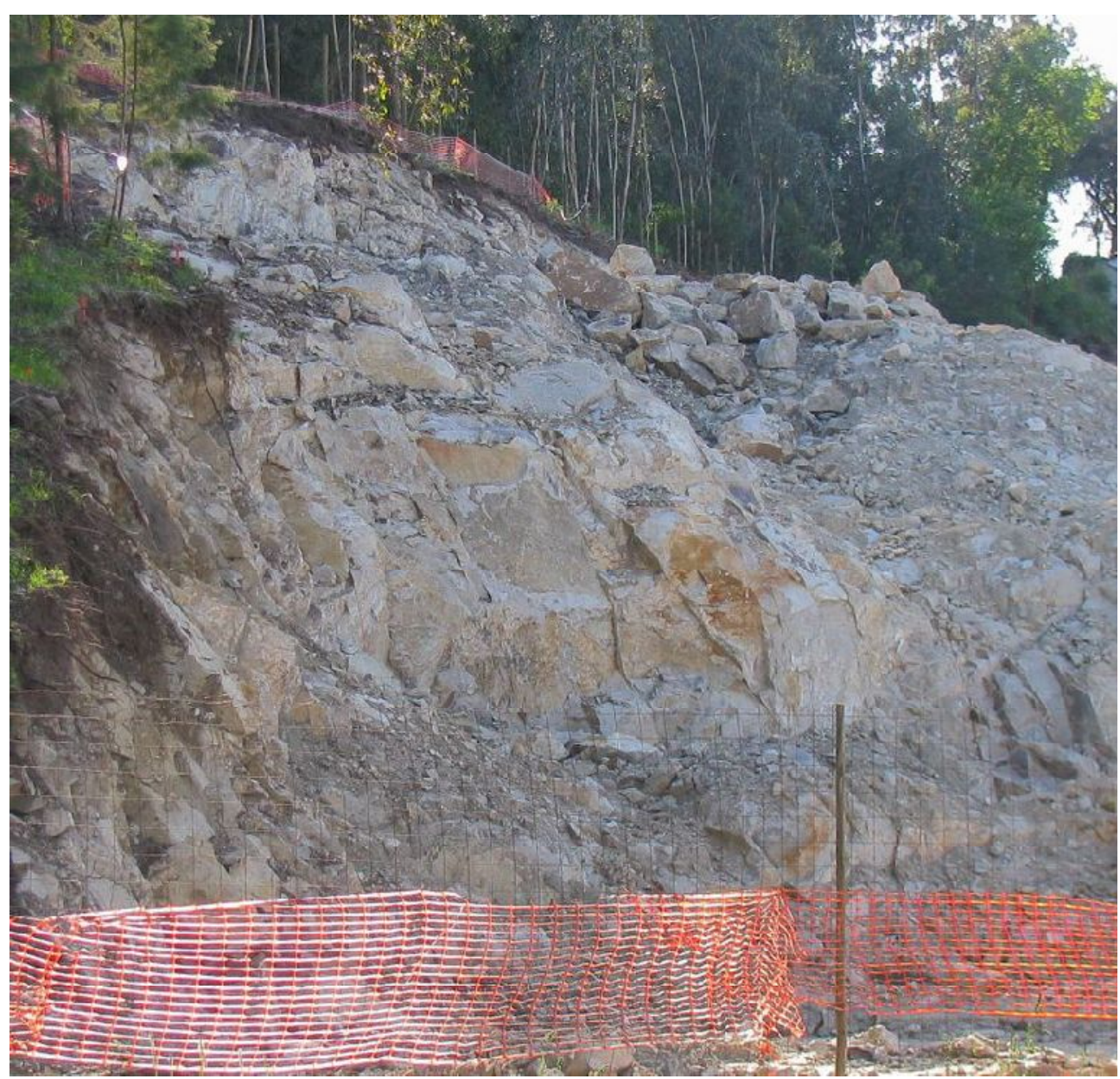

Fig.2. Road excavation in granite rock massif producing rock debris (Braga, Northern Portugal).

The questions of reusability and recyclability are intrinsically linked to stone durability. The stone that persist in a usable state can be reused when a given structure collapses or is abandoned, e.g. after extreme events such as earthquakes and fires (that leave major portions of stone in usable condition). Most alteration processes will not be an insurmountable obstacle for stone reuse. Fractured or fissured stones can favour ener- gy savings in recycling. For traditional stone blocks, erosive effects per se generally will not affect its reusability. However, situations of extreme erosion (such as in Figure 3) can have a negative impact on stone reuse potential. Additionally, erosive features result, frequently, from salt crystallization and hence they might indicate that stones are affected by salt pollution and this could imply some reserves on stone reusability and recycling. 
Soluble salts can have diverse sources (Arnold and Zenhder 1991) and its formation is not limited to seaspray or atmospheric pollution so they can be found in low urbanized places. Some stains and coatings can be considered either undesirable, namely for indoors, or conferring a (desirable) aged look, a kind of "patina of time". However, stains and coatings might also mark the presence of pollutants.

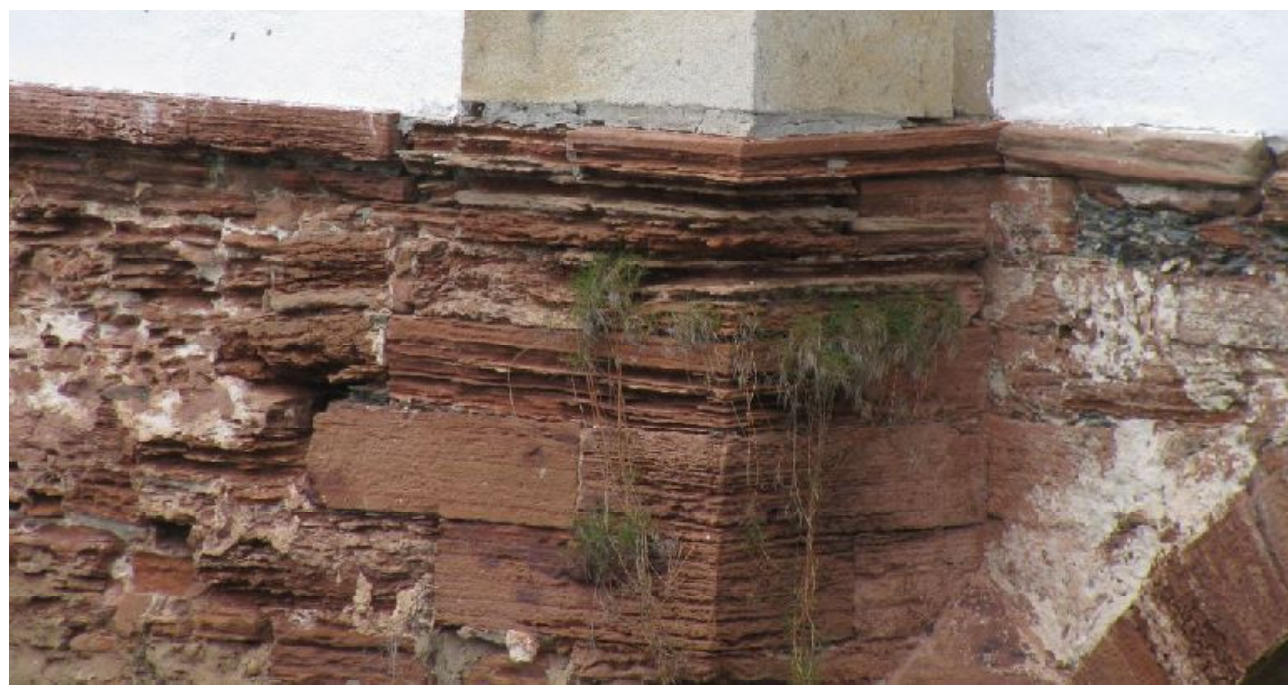

Fig. 3. Examples of sedimentary stones intense erosion that might have impact on stone reusability in a bridge in Ilhavo (Central Portugal).

In terms of energy, it will be necessary to consider impacts during extraction, transportation, maintenance and, in some cases, the use of the structure. However, for local rock in small structures using traditional techniques, the impact of the first two issues will be minimal, being null for works done directly on the rocks. The joint action of structural features (namely joints) and weathering processes (that usually are favoured by structural features) promotes geomorphological products that include loose rock blocks or blocks surrounded by more easily excavated materials (diverse examples can be found, see Twidale and Vidal Romaní 2005). Energy consumption for excavated rocks will depend on rock char- acteristics, being lower for softer rocks (including weathered rocks), but, in the case of harder rocks, structural features (such as joints) can favour excavation. In Figure $4 \mathrm{a}$ one can see penetrative joints in an outcrop of metasedimentary rocks that favour extraction of blocks with suitable dimensions for walls (as the granite blocks presented in Figure 4b). Energy impacts will be also low for loose stones whose morphological features (e.g. Figure 4c) might render them easily suitable for human use. More processed products such as stone tiles will imply higher consumption of energy (and other resources such as water and steel) due to sawing (Ioannidou et al 2014). In the same vein, crushed stone will imply greater energy consumption 
than bulk stone. But there is a certain tradition of stone hand processing (namely for walls and pedestrian and road pavements) in countries such as Portugal that will be
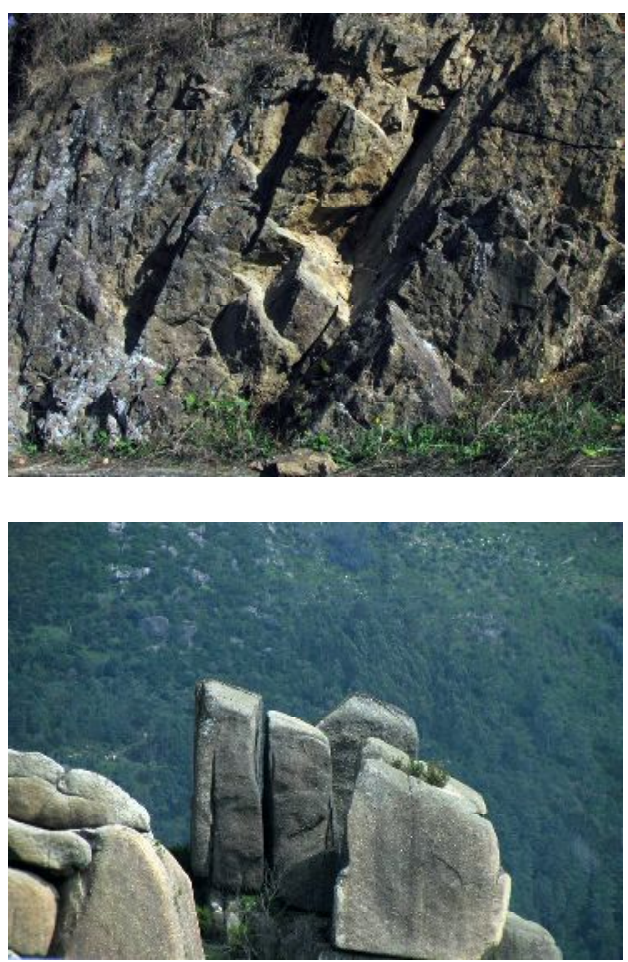

suitable to preserve from a sustainable perspective and processing can be favoured by certain rock characteristics, e.g. structural foliations (Figure 4d).
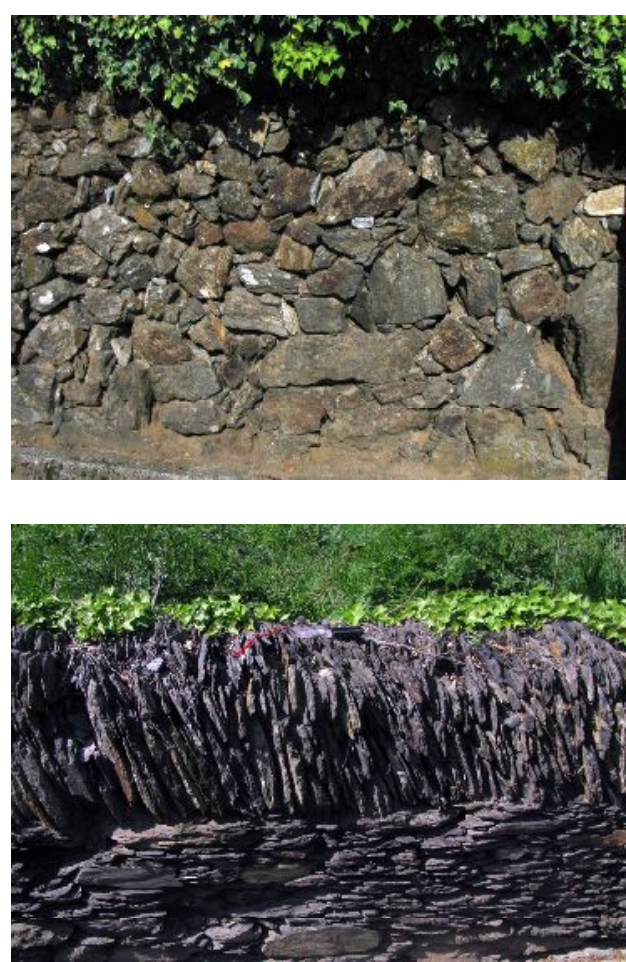

Fig. 4. Influence of structural features on rock use: a) joints in metasedimentary rocks favouring extraction of blocks with suitable size and shape in Braga (Northern Portugal); b) wall built with metasedimentary stones similar to those presented in a) in Braga (Northern Portugal); c) natural granite blocks (castle rock) in Terras do Bouro (Northern Portugal) with suitable shape for building developed along fractures; d) slate fragments resulting from parting along penetrative foliation used for walls (in Valongo, Northern Portugal).

The above considerations on durability also answer, partially, the question of energy consumption during maintenance as stone is a very durable material. Maintenance operations will involve energy consumption and it is necessary to assess the relevance of the operations to the actual goal. For example, steam cleaning might require significantly more energy than low flow cleaning (that might even be performed just by using human energy) and this can depend on the state of development of the stone alterations. For some forms of alteration it will be important to adopt an early decision on the maintenance plan to be followed. Biological colonization is the most widespread 
alteration feature on outdoor stone surfaces in rainy climates. This process shows a clear temporal evolution that begins with algae/ fungi films and might lead to more encrusted coatings such as lichens. Hence, either one accepts the development of biological colonization as a kind of natural evolution and even natural mitigation of human intrusion (see next section) or cleaning should be done as soon as signs of biological colonization are detected (since it will have lower impacts and might even done by water cleaning with human energy). We will like to refer another point: frequently, one might avoid the sustainability issues related to maintenance by doing nothing in relation to surface alterations. The question is linked to the assessment of what constitutes materials decay. One can consider that any non deliberated alteration is a form of degradation but, as referred in the previous section, it can also be proposed that some alterations are part of the ageing process or at least not undesirable (shall we try to conceals our wrinkles regardless of the cost, e.g., in terms of resources consumption, animal testing, etc.?). Some conservation options might have a positive impact in terms of energy consumption, as in the study of Arnold and Zehnder (1991), where, in order to avoid salt crystallization, it was recommended to turn off the heating system. Some maintenance interventions might also have a positive impact by improving thermal isolation (MacMullen et al. 2012) leading to lower energy consumption during the use of structures.

In terms of energy consumption, the main impacts of choosing rock materials will concern the lifetime use of the structure. This will be irrelevant for structures such as pavements or free standing structures (sculptures, walls) but it will be critical for housing. Regarding energy efficiency, rocks are poor thermal insulators due to their high thermal coefficients, which, however, can be significantly lower in very porous stones $(\mathrm{Oz}$ kahraman et al. 2006) or volcanic products like perlite (Ugur and Demirdag 2006). This issue can be worsen by moisture (as water is more conductive than air) and soluble salts (Kosior-Kazberuk and Ezerskiy 2011) and it is expectable that variations related to these agents can be higher in more porous stones (curiously, soluble salts are also being studied as phase changing materials for thermal applications-see Rempel and Rempel 2013). Thermal comfort is usually not an issue for cave dwellings since thickness promotes a good thermal insulation effect (the issue will not be discussed here but, depending on depth, there could be some heating effect underground due to the geothermal gradient). Thermal stability is also achieved in historical buildings by using thick stones. Thermal inertia can be influenced also by other materials characteristics (Aste et al. 2009) as well as by using other materials. Ultimately, it will be mostly a question of a design appropriated to local environmental characteristics (see examples in Bergman 2012). Some rocks can have important values of solar reflectance index (Pisello et al. 2014; Radhi et al. 2014), an issue very much discussed in relation to "cool materials", mostly regarding urban environments and the "heat island" effect but that can also be relevant for rural housing in hot areas. Pisello et al. (2014) found that stones with fine grain size (fine sand) have the highest solar reflectance values (but for crushed stone it will be advisable to assess the energy consumption required to obtain this finer product). Solar reflectance can be affected by alteration (Sleiman et al. 2011) which leads back to the mainte- 
nance issue. Thermal conditions can also be improved by using vegetation, "green roofs" and "green walls" (Alexandri and Jones 2008), which might also help in landscape integration (this might be achieved, at least in some situations, without intervention-see next section)

A more relevant question concerns the control of atmospheric moisture. In that regard, several rocks will be ineffective as they have low porosity, and mostly micropores, and hence will absorb water only for high relative humidity. Cave housing can also involve moisture problems because of water infiltration (this can be especially problematic for caves below the water table). There are also other parameters that can affect the desirability of stone structures such as their behaviour in terms of noise and electromagnetic isolation. These issues can be overcome using additional materials with better performance in these issues, including earth materials, which might comprise contributions from softer rock materials, including weathering products (adapting the classical example of zoned earth and rock dams and several examples in vernacular architecture).

Regarding the consumption of other resources, we will consider here their actual use for extraction, building, maintenance and structures use. There can be also destructive impacts on resources but, in that case, resources are not used (being affected as a kind of collateral damage) and those issues will be considered in the following section. Among the situations to consider, there are the use of other resources for caves stabilization and the use of earth-like materials or wood for the complementary uses referred above. The amounts involved will not be, in general, significant but special at- tention is needed regarding extraction impacts (see next section). There will be also consumption of water but, again, the scale of the structures will hardly cause a significant impact during extraction and building. More significant impacts might arise during maintenance (see Alves and SanjurjoSánchez 2015). The same considerations referred above for energy, on the need for intervention and early adoption of a maintenance plan, apply here. Cleaning operations generally involve a certain amount of water and, unless cleaning is done just with water, other substances like inorganic powders or polymers. But maintenance can also create opportunities for recycling, namely by the potential use of diverse wastes for cleaning (see examples in Grimmer 1979).

\section{POLLUTION IMPACT}

Every human activity, in general, and industrial activity, in particular, has some impact on the environment, positive or negative, more or less difficult to ameliorate and minimize. This section will be structured around three main lines: (i) landscape alteration, (ii) radioactive impact, (iii) other pollutants, (iv) wastes. Rock extraction and rock structures can be considered landscape alteration activities and, hence, in a perspective of considering pollution any alteration of the natural, pristine, state, can be looked upon as causing (visual) pollution. It has been referred that landscape reintegration of quarrying activities can be difficult, as illustrated by slate quarrying in NW of Iberia (Gutierrez del Rey 2010). But, once more, one should consider the intensity of the alteration. In ECO-STONE (2013) is estimated that to produce stone tiles for the average floor area of a modern house (7 
tonnes of stone), it will be necessary to extract 100 tonnes of stone. If one considers a bulk density value of $2 \mathrm{t} / \mathrm{m}^{3}$ (which can be considered a conservative value for the purposes of stones) and assuming a exploitation depth of, say, $2 \mathrm{~m}$, this will correspond to a square hole with around $5 \mathrm{~m}$ side. For the small scale considered here, it is possible that landscape remediation of these extraction scars occurs naturally, as is illustrated in Figure 5, where a rock road slope with less than five years is already showing signs of natural revegetation. Our experience also indicates that it is frequently hard to identify historical quarries since most are covered with vegetation.

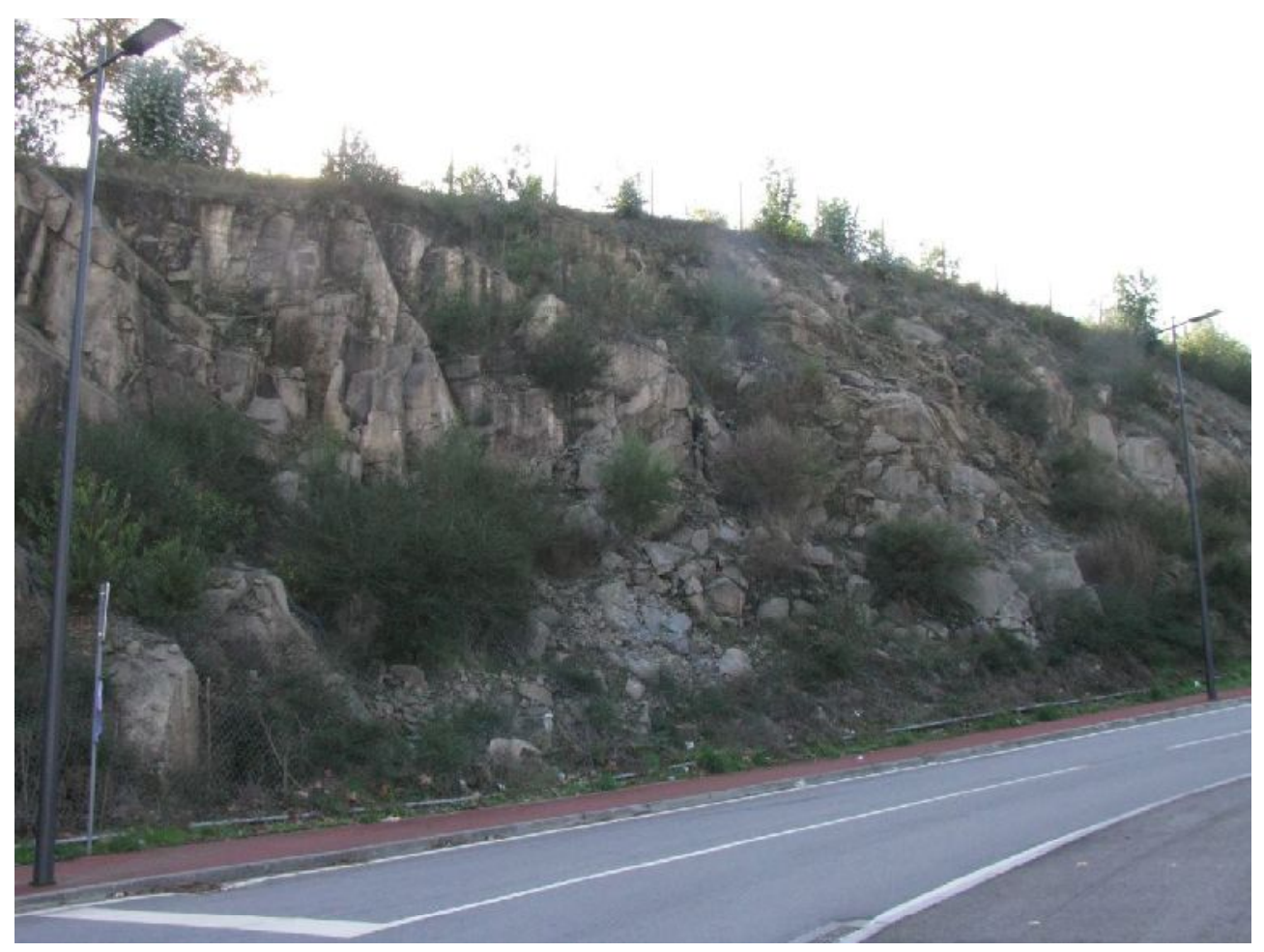

Fig. 5. Example of revegetation of a granite road slope with less than five years in Braga (Northern Portugal).

Stoneworks can be considered a form of pollution, an intrusion in the natural landscape. But structures with local stone will not be very different from local outcrops. There are also diverse evidences of the compatibility of animals and plants with stoneworks, which are part of what Juncà et al. (2016) call biotopes of the grey system.
As discussed above, stone suffers diverse surface alteration, being one of the commonest biological colonization (e.g. Figure $6 a, b)$. Stones can present high critical moisture under drying (moisture that evaporates from non-surface pores) and, hence, drying is much slower than when moisture is at the surface, keeping the substrate moist during 
longer times, favouring the development of biological colonization. Traditional stoneworks structures, especially with open or lime mortar joints, have favourable conditions for biological colonization and even biological diversity (Ariño and Saiz-Jimenez 1996), which promotes the visual integration in the landscape. The relatively fast development of biological colonization is common on rainy temperate regions but it is expectable that also on dry hot and cold ones climates stoneworks will be favourable as they can offer shaded protected places where moisture remains for longer time. The examples presented in Figure 6c show a kind of natural remediation of man intrusion and the rehabilitation for human use of these structures might not be incompatible with the preservation of the intense biological colonization. This also relates to the soft capping procedures mentioned above, contributing to improve thermal conditions and landscape integration.

Quarrying can generate a number of other on-site and off-site environmental pollution effects (a more comprehensive review can be found in EC 2010). Extraction, building and maintenance can affect ecological sensible resources as, e.g., sand from recharge areas (Al-Agha 2006) or river areas (Dias et al. 2008). Landscape alteration due to extraction and building can affect groundwater recharge areas, especially when recharge is related to certain stratigraphic units that might be disturbed by extraction or that might be cut from infiltration waters. Affecting groundwater recharge areas might have impacts on water resources for humans and have ecological impacts (see examples in Ribeiro 2013). Small works like those considered here are not expected to have a significant impact on surface water even if some questions can arise when extraction occurs in or near river banks. Landscape alteration can also increase pollution hazards of groundwaters by striping soil and vegetation as these elements are considered to have a protective effect on groundwaters (see DRASTIC model-Aller et al. 1987). Another issue concerns the destruction of forest and agricultural resources but in certain regions these impacts will not be on the table since, as referred above, some rocky areas are not favourable to these resources (they might even be absent) and there will be ways to minimize impacts e.g. by micromanaging the location of extraction points or by using loose stones (but this is not totally devoid of problems as some rocks might have ecological importance-see examples in Nikulinsky and Hopper 2008). Regarding cave housing, it will be advisable to perform ecological and archaeological evaluations of existing caves to avoid destruction of habitats and historical heritage. 


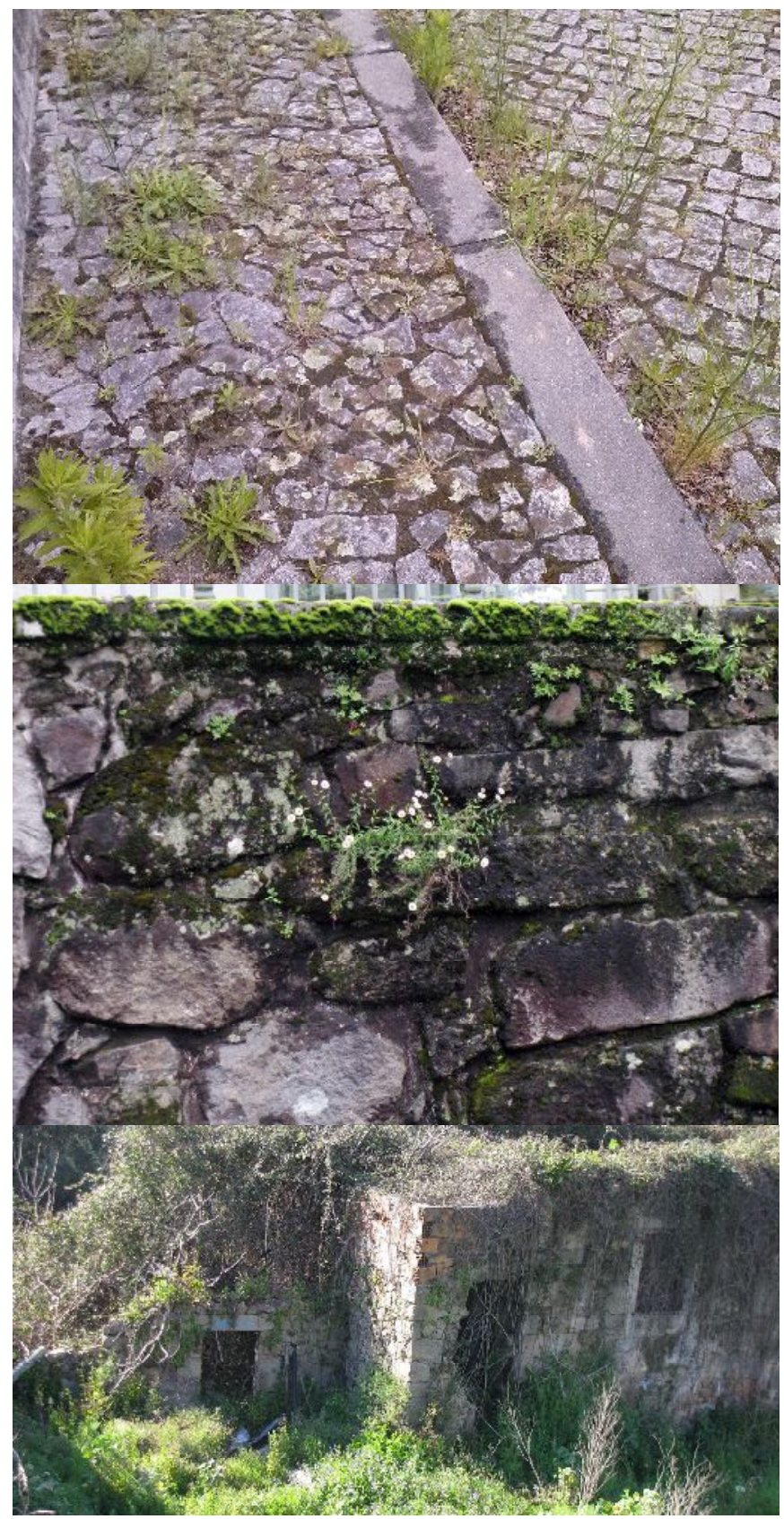

Fig. 6. Examples of extensive biological colonization on granite stone pavements in Braga (Northern Portugal) (a) and wall (b) and almost engulfing an abandoned masonry structure in Braga (Northern Portugal) (c). 
Possibly the main issue in terms of pollutants emission linked to rock materials concerns radioactivity (external gamma radiation, radon and particles inhalation and ingestion) that present higher hazards in indoor spaces (see Markkanen 1995). This includes cave housing (see Nuccetelli et al. 2014). Radiological hazards will depend on intrinsic characteristics of rocks such as radioisotopes contents, density and permeability. In terms of external gamma radiation, there are proposals for assessing the hazard level related to a material using an index calculated from radioisotopes contents (Markkanen 1995), with guidance values assuming a specific model for materials density, amount and spatial distribution (it assumes that the material is used in all the indoor surfaces of the space), as well as a specific space dimension and exposition time. The dose related to gamma external radiation from building materials decreases, linearly, with exposure time (so little used spaces will have low hazard levels) and it also decreases with smaller materials amounts (see EC 1999) and decreasing materials density (Nuccetelli et al. 2015). Some rock materials are expected to have higher radioactive levels (see Kovler 2012) such as carbonatites, alum shale, granites, tuffs etc. Other rocks can present very low radioactive elements contents, e.g. ultramafic rocks (Kobranova 1989; Gómez et al. 2011). Even for the more worrisome rock types there are variations so there are, e.g., granite types presenting low radiological risks. The issue could be more worrisome when natural radioactive wastes, namely from uranium explorations, are used in building mortars (Thomas and Drábová 1993).

Regarding the more radioactive rock materials, using other materials as coatings can have a shielding effect (see simulations in Markkanen 1995) and this has the side effect, in sustainability terms, of creating opportunities for using less radioactive materials, either soils or less radioactive stones (it might even be possible to build rooms with gamma radiation levels below the natural conditions of a region, providing a justification for stone importation). Some rocks might have lower radiation levels than other common materials (in the study by Trevisi et al. 2012, mean values of analysed metamorphic rocks were above mean values of natural gypsum but below mean values of brick, concrete and cement).

In terms of radon emissions, and considering the model proposed in Markkanen (1995), besides the content of radioactive isotopes in the rock materials, hazard levels depend on the area of applied material, space volume and air renovation rate, so decreasing hazard might be simply a question of keeping the indoor space well aerated (for a discussion of ventilation effects on radon levels see Akbari et al. 2013; a review of other models and procedures for radon remediation is presented in Pacheco-Torgal 2012). In addition, less radioactive and less permeable materials can be used indoors as barriers to radon migration.

Another issue related to radiological hazards due to materials concerns the inhalation and ingestion of particles. Markkanen (1995) indicates a relation with the inhaled and ingested amounts of particles, which depend on particles amounts on the air. It is not expectable that normal indoor housing conditions create significant dust levels but this issue might be affected by the surface state of the materials and it might be minimized by aeration or by coating the materials. 
The use of stone can generate other pollutants during extraction and transport, but, again, for local rocks used in small structures these impacts will be minimal. The emissions of pollutants will also be affected by the processing procedures, being higher for products that demand higher processing such as cladding (Ioannidou et al. 2014). According to SFGB (2011), the greatest carbon impact related to natural stone results from processing (which will be much minimized for the vernacular structures here considered). The emplacement of rock cut surfaces might promote reactivity and hence pollution release. However, the present state of knowledge suggests that the amount chemical weathering of stone (and substances leaching) is minimal in the built environment.

Maintenance operations can be also a source of pollution as certain intervention measures emit potentially dangerous substances and produce wastes (see review in Alves and Sanjurjo-Sánchez 2015). Excepting the extensive application of biocides, the production of pollutants due to interventions will not be very significant. However, some interventions such as stone desalination by poultices might generate waste that, since they are contaminated with salts, can require some ingenuity to recycle. And of course, the same considerations regarding non-intervention policy and the need for adoption of an early decision will apply to this case.

Dust emission from quarries is not expectable to be significant for the considered scale of operations but the presence of asbestiform minerals can cause concerns (Perkins et al. 2008; Wylie and Candela 2015). In general rock materials do not cause significant atmospheric emissions by its use in- doors but, again, asbestiform minerals might deserve special attention. This issue needs also to be considered in derived materials as there are evidences that point to examples of whitewash incorporating asbestiform minerals that contribute to pneumological issues (Constantopoulos 2008). There are references to the hazard of particles emissions from nanomaterials (Warheit et al. 2008) but we were not able to find any reference to potential release of nanoparticles from rocks and as the amount in nanoparticles in natural rocks is generally extremely small this does not seem to be a motive of concern. However, considering the analyses of Navrotsky (2004) on natural nanoparticles, we do not exclude the possible relevance of this issue for volcanic ash materials or granular materials resulting from weathering. In general, stone use also avoids issues related to emissions from additives (but this might change due to some maintenance interventions).

Quarrying activities might also contribute to noise pollution due to preparatory activities, such as establishing road or rail access, mineral processing facilities, scraping or excavation of the top soil, extraction of the rock, transport of the extracted materials or even processing plants to crush and grade the minerals, but as we have been discussed, this will depend on the size of the operation and processing options.

Wastes were left for the end of the section as we think this can be an appropriate bridge for the next section. Stone production is sometimes considered a very wasteful operation. The ECO-STONE (2013) data considered above indicates $97 \%$ waste in mass but this refers to one application type (stone tiles) and, as already mentioned briefly in the previous section, rock wastes have a potential for reuse and recycling. The ques- 
tions raised in the previous section regarding reusing and recycling stones will also apply to rock wastes and one must also pay attention to certain pollution issues that might be exacerbated in wastes as in the uranium-rich wastes mentioned above.

\section{FURTHER COMMENTS ON POSITIVE IMPACTS OF THE USE OF ROCK MATERIALS}

After discussing the main objections that can be raised in relation to using rock materials, namely stones, we will consider some additional possible positive impacts that favour the use of these materials (additional since, as was seen, some of the issues that might be considered negative can have positive side effects, namely in terms of wastes as resources).

Trivially, stone exploitation generates revenue and creates employment. While being somehow outside the scope of this work, it will be appropriated to highlight that stone production might be an important source for the sustainability of communities in isolated regions where no other major enterprises exist and that are not very seductive for industrial operations.

Additionally, stone extraction (and, as referred above, engineering and agricultural works) can generate rocky waste that can be reused and recycled, and this will create business opportunities, as is show by examples from historical and modern works, including applications with positive environmental impact. Since the transport and deposition of waste in landfills involve significant costs, its incorporation in other industrial processes could lead to the reduction of costs and open new business opportunities, while reducing the volume of extraction of raw ma- terials, preserving limited natural resources. Thus, recycling of waste emerges as an opportunity to transform expense into profit.

Industrial corporations and researchers have been looking for alternative uses of the waste beyond their storing. These uses include construction of embankment fills and road pavements and their use in building materials such as additive for tile production (Albarrán-Lisoet al. 2006; Navarro et al. 2008). Thus, it has been studied the use of stone cutting wastes in several industries, and mostly in the ceramic industry. A clear example of this is the waste produced by granite and marble cutting. These inexpensive residues can be regarded as good substitutes for costly raw materials, preserving mineral resources, solving environmental problems and lowering production costs. Granite has, as major constituents, feldspar, quartz and mica, while marble is basically constituted of calcite. Wastes of both rock types can be classified as fluxes (they have the potential to act as glassy phase formers during the sintering process) improving the sinterability of the clay material. The effect of small additions to clay mixtures has been investigated (Acchar et al. 2006), and it has been observed that the final properties of the fired products do not change drastically. It has also been shown (Acchar et al. 2006) that higher contents of marble and granite rejects can be used to enhance the processing of clay products, enabling firing at lower temperatures. These materials also have a non-plastic character. Thus, they can play an important role as plasticity-controllers during fabrication. In some similar tests, it has been found that producing roof tiles incorporating $10 \%$ of granite wastes results in tiles of excellent properties. Therefore, the sludge derived from the granite cutting and 
polishing industries can be classified as a by-product suitable to replace natural nonplastic raw material in traditional ceramic formulations. Some rocky materials can also be recycled in other building products and even contribute to cement substitution (Ramezanianpour 2014) with a global positive impact in terms of sustainability (as it can contribute to $\mathrm{CO} 2$ emissions reduction).

We can consider two additional examples related to issues already discussed. One example concerns using rocks as cool materials for stabilization of railway tracks by avoiding terrain movements resulting from thawing ( $\mathrm{Li}$ et al. 2008). Another example, related to thermal properties, concerns using rock materials for energy production due to their capacity for heat storage (Tiskatine et al. 2016). There are also business opportunities related to stone reuse (there is commerce of old stone, that sometimes can include illegal operations, which can be considered also a mark of reusability).

The use of underground space is a current subject of study in urban areas due to questions associated with space scarcity (Bobylev and Sterling 2016) but there are also several positive impacts related to the occupation of natural and excavated cavities (including underground quarrying and mining works) in rural regions. Natural and excavate rock holes can pose a hazard to humans. So their occupation might treat two issues. Using cavities diminish surface space occupation and landscape impact. Besides diminishing their sustainability impact, the occupation of underground mining spaces might even contribute to their economic viability. There are several other activities that have been proposed for cavities (Broch 2016) and one can highlight that natural and excavated holes are being sought after for data centres (Miller 2009) because of thermal conditions and even its ability to resist military (even nuclear) attacks (but moisture can be a particularly relevant problem for this kind of use).

Another economically relevant perspective concerns touristic activity. Quarries expose rocks that would not otherwise be seen and they often expose a range of rock types. Moreover, quarries have fresh broken faces which clearly display rocks features. There are also opportunities for using mines as exemplified by the coal mines of Meirama and As Pontes (Northwestern Spain), which were reintegrated in the landscape allowing gap filling excavation by local waterways and rain to get new lakes that can be used with amusement purposes and water storing (Samper et al., 2008; Delgado-Martín et al., 2015). Moreover, old Roman gold mines that caused a strong damage to the landscape are an important source for tourism mining archaeology in some parts of Spain as occurs with "Las Medulas", included in the list of World's Heritage since 1997 (Sánchez-Palencia et al., 2000).

Stone structures can be "windows" on the local geology and be seen as a link to nature, being useful for touristic promotion, preferably not mass tourism but tourism sensible to science and technical knowledge. These "windows" on the geological environment can also have a value for teaching at several levels, from primary school to college, which can be linked to tourism, for educational activities for city dwellers.

Rock materials might indeed have the highest touristic potential among building materials as they can have unique (petrological) features at a worldwide level. One can also refer to the historical example of the Orvieto caves in Italy (presently being 
used as touristic housing). These perspectives (products, tourism, education) can be extended to rock extraction, excavation and stoneworks craftsmanship, as is illustrated in Figure $4 b$ (the building of a stone structure, selecting the appropriated material, can be an experience in dealing with nature, as is illustrated by a passage in Walden, that classic work of sustainability literature, Thoreau wrote "I laid the foundation of a chimney at one end, bringing two cartloads of stones up the hill from the pond in my arms"). One might also risk saying that stoneworks "age" better than other building materials (and hence have a more longstanding touristic potential).

There could be also some positive ecological impacts. In EC (2010) is referred that "If planned properly, modern non-energy extractive industry (NEEI) activities can actively contribute to biodiversity conservation", and this documents presents diverse examples illustrative of this claim.

\section{FINAL CONSIDERATIONS}

As can be seen in several examples, quantitative assessments can be fraught with complexities (see Pilkey and PilkeyJarvis 2007) and the results will be largely dependent on the importance attributed to the parameters considered. Hopefully, this qualitative analysis has contributed to establish a conceptual framework regarding the parameters and relations to consider in assessing rock materials sustainability. As a grand final synthesis we will risk to say that rock materials are potentially sustainable but the last word belongs to design options (and the coordination of those options at several stages, "from cradle to grave" to use a classic sustainability saying). Our fi- nal comments will be base around the three components proposed by Finkbeiner et al. (2010).

In terms of environmental impact our main contention was that, for the conditions involved in the uses presented here (that can be summarised as "small and local"), impacts will not be, in general, significant, given that materials are used in the same natural context and considering the low intensity of the identified impacts. Rock extraction marks and rock structures can be re-integrated in the natural landscape (for the evaluation of the visual impact it might be suitable to assess the biological colonization rate in the region) and it is assumed that there will be an almost integral use of the extracted rock materials. In an environmental hierarchy of functional materials and structures, one can defend that rock overcomes concrete, metals and polymers. Timber could be considered best from a renewable point of view but its durability might affect its functionality and it is necessary to assess the impacts related to produce amounts of timber similar to available stone. The promotion of the use of rock materials can have additional positive impacts as promoter of reuse and recycling of rock wastes from other activities such as roads, bridges, dams, etc. Given the environmental costs of recycling (including transportation to the recycling structure), the promotion of a culture of rock use in loco can help to reuse and recycle rock wastes from other activities (roads, bridges, dams, etc). However, the environmental impacts of extraction operations and cave occupation might become significant when they affect sensible areas from an environmental or cultural point of view. These can be considered the main factors to analyse in a sustainable assessment of rock materials for small struc- 
tures in rural areas, namely as they require a detailed assessment at a small scale (since small disturbances in specific spots can have disproportionate effects, e.g., if they cause disturbs in the recharge of springs or irreversible damage to cultural heritage or specific habitats of endangered species).

In terms of social impact one should not ignore the cultural significance usually attributed to rock structures and the processes for their building. This is also a potential field for applied psychology, as the decision on whether stone weathering has positive or negative effects can have sustainability implications related to maintenance operations and the effects (valuing/penalising) on the reusability and recyclability of stone. It will be also interesting to assess how the new uses of rock underground caves will affect the legal management of underground space and its impacts on regional communities.

Finally, regarding economic impacts, besides potential contributions to the welfare of isolated and depressed regions, there are valuable touristic options regarding rock excavations, increasing the visibility of the geological background and contributing to landscape visual diversity, and regarding the cultural value of rock structures (both in terms of materials and techniques). Additionally, as was mentioned above, rock cave spaces can have new uses that are rephrasings of old ones and these can present a great strategic importance. The culture of in loco rock use can also have economic impact, as frequently the entity responsible for building a given structure is legally bound to deal with resulting wastes.

Our final paragraph concerns, albeit very briefly, what could be considered the main counterexample regarding rock materials sustainability of rock materials: the case of the famous moai rock statues of the Rapa Nui in Easter Island. Accepting the hypothesis that this settlement collapse was due to excessive resource consumption for making and transporting the rock statues (see Rainbird 2002), considering the tenets of this paper, we can suggest that this was a question of scale and location, as the number and size of statues was excessive and resources were massively consumed in their transportation. Hence, this case can be considered to be outside the "small and local" limits of our discussion.

\section{ACKNOWLEDGMENTS}

The Lab2PT-Landscapes, Heritage and Territory laboratory-AUR/04509 is supported by the Portuguese Fundação para a Ciência e a Tecnologia (national funds and when applicable of the FEDER co-financing, in the aim of the new partnership agreement PT2020 and COMPETE2020-POCI 010145 FEDER 007528). The University Institute of Geology of the University of A Coruña (Spain) receives support from Xunta de Galicia with funds from "Consolidación y estructuración de unidades de investigación competitivas - Grupo de potencial de crecimiento" (GPC2015/024).

\section{REFERENCES}

ACCHAR W, VIEIRA, F.A.; SEGADÃES, A.M. (2006) Using ornamental stone cutting rejects as raw materials for red clay ceramic products: Properties and microstructure development. Mater Sci. Eng: A 435-436:606-610. DOI:10.1016/j. msea.2006.07.091

AKBARI, K.; MAHMOUDI, J.; GHANBARI, M. (2013) Simulation of ventilation effects on indoor radon. Man- 
agement of Environmental Quality: An International Journal, 24, 394-407. DOI: $10.1108 / 14777831311322686$

AL-AGHA, M. R. (2006) Weathering of building stones and its relationship to the sustainable management of the aggregate resources in Gaza Strip, Palestine. Build Environ. 41:676-686. DOI:10.1016/j.buildenv.2005.02.012

ALBARRÁN-LISO, C.; JORDÁN-VIDAL, M. M.; SANFELIU-MONTOLIO, T.; LISO-RUBIO, M. J. (2006) Alteration, evaluation and use of extremaduran granite residues. Environ Geol. 49:1043-1050. DOI:10.1007/ s00254-005-0148-2

ALEXANDRI, E.; JONES, P. Temperature decreases in an urban canyon due to green walls and green roofs in diverse climates. Build Environ. 2008, 43, 480-493. DOI:10.1016/j.buildenv.2006.10.055

ALLER, L.; BENNETT, T.; LEHR, J.H.; PETTY, R.J.; HACKETT G., DRASTIC: A standardized system for evaluating ground water pollution potential using hydrogeologic settings. NWWA/EPA Series, EPA-600/2-87-035; US Environmental Protection Agency: Washington, DC, USA, 1987.

ALVES, C.; SANJURJO-SÁNCHEZ, J. MAINTENANCE AND CONSERVATION OF MATERIALS IN THE BUILT ENVIRONMENT. In Pollutants in Buildings, Water and Living Organisms; Lichtfouse, E.; Schwarzbauer, J.; Robert, D., Eds.; Springer International Publishing: Cham, Switzerland, 2015; Vol. 7, pp. 1-50. DOI:10.1007/9783-319-19276-5_1

ANIL KUMAR, P.P. Overview of Natural Stones as an Energy Efficient and Climate Responsive Material Choice for Green Buildings. In Implementing Campus Greening Initiatives; Leal Filho, W.; Muthu, N.; Edwin, G.; Sima, M., Eds.; Springer International Publishing: Cham, 2015; pp. 27-35. DOI:10.1007/978-3-319-11961-8_3

ARIÑO, X.; SAIZ-JIMENEZ, C. BIOLOGICAL DIVERSITY AND CULTURAL HERITAGE. AEROBIOL. 1996, 12, 279-282. DOI:10.1007/ BF02248165

ARNOLD A, ZEHNDER K (1991) Monitoring wall paintings affected by soluble salts. The Conservation of wall paintings; Cather, S.; Courtauld Institute of Art; Getty Conservation Institute, Eds.; Getty Conservation Institute: Marina del Rey, USA, 1991, p. 103-135.

ASTE, N.; ANGELOTTI, A.; BUZZETTI, M. The influence of the external walls thermal inertia on the energy performance of well insulated buildings. Energ Build 2009, 41, 1181-1187. DOI:10.1016/j.enbuild.2009.06.005

BARBERO-BARRERA, M.M.; GIL-CRESPO, I.J.; MALDONADO-RAMOS, L. Historical development and environment adaptation of the traditional cavedwellings in Tajuña's valley, Madrid, Spain. Build Environ. 2014, 82, 536-545. DOI:10.1016/j.buildenv.2014.09.023

BERGE, B. The ecology of building materials; English translation by Filip Henley, Architectural Press: Oxford, USA, 1992.

BERGMAN, D. Sustainable design a critical guide; Princeton Architectural Press: New York, USA, 2012.

BOBYLEV, N.; STERLING, R. Urban underground space: A growing imperative. Tunnell Undergr Space Technol. 2016, 55, 1-4. DOI:10.1016/j.tust.2016.02.022 
BROCH, E. Planning and utilisation of rock caverns and tunnels in Norway. Tunnell Undergr Space Technol. 2016, 55, 329 338. DOI:10.1016/j.tust.2015.08.010

CANTER, L. W. Environmental impact assessment; McGraw-Hill series in water resources and environmental engineering; 2nd ed.; McGraw-Hill: New York, USA, 1996.

CONSTANTOPOULOS, S. H. Environmental mesothelioma associated with tremolite asbestos: Lessons from the experiences of Turkey, Greece, Corsica, New Caledonia and Cyprus. Regul Toxicol Pharmacol. 2008, 52, S110-S115. DOI:10.1016/j.yrtph.2007.11.001

DELGADO-MARTÍN， J., JUNCOSARIVERA, R., JARDÓN-CAVERO, A., GONZÁLEZ-PHILIPPON, R., FERNÁNDEZ-GARCÍA， A. (2015) Integrating pit lakes into water basin planning: the Meirama brown coal mine. In: Responsible mining. Case studies in managing social \& environmental risks in the developed World (Jarvie-Eggart, M.E., ed.). Society for Mining, Metallurgy \& Exploration Inc. pp. 489-515.

DEUTSCH, D. The beginning of infinity: explanations that transform the world; Penguin Books: London, UK, 2012.

DIAS, W.P.S.; SENEVIRATNE, G.A.P.S.N.; NANAYAKKARA, S.M.A. Offshore sand for reinforced concrete. Construct Build Mater. 2008, 22, 1377-1384. DOI:10.1016/j.conbuildmat.2007.04.006

EC -EUROPEAN COMMISSION; Directorate-General for the Environment. EC guidance on undertaking non-energy extractive activities in accordance with Natura 2000 requirements; EUR-OP: Luxembourg, 2010.

ECOSTONE, ECOSTONE Sustainable
System Implementation for Natural Stone Production and Use. FINAL REPORT. 2013. Available online: http:// ec.europa.eu/environment/life/project/ Projects/index.cfmfuseaction $=$ home . show File \& rep = file \&fil=LIFE0 8 ENV_E_000126_FTR.pdf (accessed on 11 May 2016).

EUROPEAN COMMISSION. Radiation Protection 112 - Radiological protection principles concerning the natural radioactivity in building materials. European Commission: Luxembourg, 1999.

FINKBEINER, M.; SCHAU, E. M.; LEHMANN, A.; TRAVERSO, M. Towards Life Cycle Sustainability Assessment. Sustainab. 2010, 2, 3309-3322. DOI:10.3390/su2103309

GOLANY, G. DESIGN and thermal performance: below-ground dwellings in China. University of Delaware Press: Newark, USA, 1990.

GÓMEZ, D. P., NEVES, L., PEREIRA, A., \& NEILA, C. G. (2011). Natural radioactivity in ornamental stones: an approach to its study using stones from Iberia. Bull Eng Geol Environ. 70(4), 543-547. http://doi.org/10.1007/s10064011-0389-0

GOMEZ-HERAS, M.; MCCABE， S.; SMITH, B. J.; FORT, R. Impacts of Fire on Stone-Built Heritage: An Overview. J Architect Conserv. 2009, 15, 47-58. DOI :10.1080/13556207.2009.10785047

GRIMMER A.E. (1979) Dangers of Abrasive Cleaning to Historic Buildings. Preservation Briefs n. ${ }^{\circ}$ 6, National Park Service, U.S. Department of the Interior.

GUTIERREZ DEL REY, F. La explotación de pizarras en Galicia y sus impactos ambientales. $\mathrm{PhD}$ Thesis. Universidade da Coruña: A Coruña, Spain, 2010. 
IOANNIDOU, D.; ZERBI, S.; HABERT, G. When more is better - Comparative LCA of wall systems with stone. Build Environ. 2014, 82, 628-639. DOI:10.1016/j.buildenv.2014.10.004

JUNCÀ, M.B.; ZARAGOZA, R.M.; GUELAR, P.K. The Vital Role of Biodiversity in Urban Sustainability. In Can a city be sustainable? Gardner, G. T.; Prugh, T.; Renner, M., Eds; Worldwatch Institute: Washington, DC, USA, 2016.

KOBRANOVA, V.N. Petrophysics. Springer-Verlag: Berlin, Deutschland, 1989.

KOSIOR-KAZBERUK, M.; EZERSKIY, V. Method of prediction of thermal conductivity coefficient of wall materials containing salts. Jop Civil Eng Manag. 2011, 17, 108-114. DOI:10.3846/139237 30.2011.554019

KOVLER, K. RADIOACTIVE MATERIALS. IN TOXICITY OF BUILDING MATERIALS; TORGAL, F. P.; JALALI, S.; FUCIC, A., Eds.; Woodhead Publishing in materials; Woodhead Publishing: Cambridge, UK, 2012; pp. 196240. DOI:10.1533/9780857096357.196

LI, G.; LI, N.; KANG, J.; NIU, F.; YU, W.; SHI, L.; BI, G. Study on design optimization of a crushed stone layer with shading board placed on a railway embankment on warm permafrost. Cold Regions Sci Technol. 2008, 54, 36-43. DOI:10.1016/j.coldregions.2007.11.004

MACMULLEN, J.; ZHANG, Z.; RADULOVIC, J.; HERODOTOU, C.; TOTOMIS, M.; DHAKAL, H. N.; BENNETT, N. Titanium dioxide and zinc oxide nano-particulate enhanced oil-inwater $(\mathrm{O} / \mathrm{W})$ facade emulsions for improved masonry thermal insulation and protection. Energ Build. 2012, 52:8692. DOI: $10.1016 /$ j.enbuild 2012.05 .027
MAGNUSSON, S.; LUNDBERG, K.; SVEDBERG, B.; KNUTSSON, S. Sustainable management of excavated soil and rock in urban areas - A literature review. J Cleaner Produc. 2015, 93:18-25. DOI:10.1016/j.jclepro.2015.01.010

MARKKANEN, M. Radiation Dose Assessments for Materials with Elevated Natural Radioactivity. Report STUKB-STO 32 Radiation and Nuclear Safety Authority - STU. Finnish Centre for Radiation and Nuclear Safety: Helsinki, Finland, 1995.

MILLER, R. The Data Bunker Boomlet. 2009. Available online: http:// www.datacenterknowledge.com/archives/2009/07/14/the-data-bunkerboomlet/ (accessed 11/May/2016).

MINKE, G. Building with Earth; Birkhäuser Basel: Basel, Switzerland, 2006. DOI:10.1007/3-7643-7873-5

MOREL, J. .; MESBAH, A.; OGGERO, M.; WALKER, P. Building houses with local materials: means to drastically reduce the environmental impact of construction. Build Environ. 2001, 36:1119-1126. DOI:10.1016/S03601323(00)00054-8

NAVARRO, V.; BARRIENTOS, V.; YUSTRES, Á.; DELGADO, J. Settlement of embankment fills constructed of granite fines. Comput Geosci 2008, 34:978-992. DOI:10.1016/j.cageo.2007.07.007

NAVROTSKY, A. Environmental Nanoparticles. In Dekker Encyclopedia of Nanoscience and Nanotechnology, Volume 2, Schwarz, J. A.; Contescu, C. I.; Putyera, K., Eds.; M. Dekker: New York, USA, 2004, pp. 1147-1156.

NIKULINSKY, P.; HOPPER, S. D. Life on the rocks: the art of survival; Fremantle Press: Perth, Australia, 2008. 
NUCCETELLI, C.; LEONARDI, F.; TREVISI, R. A new accurate and flexible index to assess the contribution of building materials to indoor gamma exposure. J Environ Radioactiv. 2015, 143:70-75. DOI:10.1016/j.jenvrad.2015.02.011

NUCCETELLI, C.; TREVISI, R.; AMPOLLINI, M.; CARDELLINI, F.; TONNARINI, S.; KOVLER, K. Radiological characterization of the ancient Roman tuff-pozzolana cave in Orvieto (Italy). Proceedings of the EU-NORM2 Symposium, Czech Republic, June, 17 19, 2014.

OZKAHRAMAN, H.T.; BOLATTURK, A. The use of tuff stone cladding in buildings for energy conservation. Construct Build Mater. 2006, 20:435-440. DOI:10.1016/j.conbuildmat.2005.01.064

PACHECO-TORGAL，F. Indoor radon: An overview on a perennial problem. Build Environ. 2012, 58:270-277. DOI:10.1016/j.buildenv.2012.08.004

PERKINS, R. A.; HARGESHEIMER, J.; VAARA, L. Evaluation of Public and Worker Exposure Due to Naturally Occurring Asbestos in Gravel Discovered During a Road Construction Project. J Occup Environ Hygiene 2008, 5:609616. DOI:10.1080/15459620802289941

PILKEY, O. H.; PILKEY-JARVIS, L. Useless arithmetic: why environmental scientists can't predict the future; Columbia University Press: New York, USA, 2007.

PISEllO, A.; PIGNATTA, G.; CASTALDO, V.; COTANA, F. Experimental Analysis of Natural Gravel Covering as Cool Roofing and Cool Pavement. Sustainab. 2014, 6:4706-4722. DOI:10.3390/ su6084706

RADHI, H.; ASSEM, E.; SHARPLES, S. On the colours and properties of build- ing surface materials to mitigate urban heat islands in highly productive solar regions. Build Environ. 2014, 72:162-172. DOI:10.1016/j.buildenv.2013.11.005

RAINBIRD, P. A message for our future? The Rapa Nui (Easter Island) ecodisaster and Pacific island environments. World Archaeol. 2002, 33:436-451. DOI:10.1080/00438240120107468

RAMEZANIANPOUR, A. A. Cement Replacement Materials; Springer Geochemistry/Mineralogy; Springer Berlin Heidelberg: Berlin, Heidelberg, 2014. DOI:10.1007/978-3-642-36721-2

REMPEL, A.; REMPEL, A. Rocks, Clays, Water, and Salts: Highly Durable, Infinitely Rechargeable, Eminently Controllable Thermal Batteries for Buildings. Geosci. 2013, 3:63-101. DOI:10.3390/ geosciences 3010063

RIBEIRO, L., ED.; Groundwater and ecosystems; Selected papers on hydrogeology; 1st ed.; CRC Press/Balkema: Leiden, The Netherlands, 2013.

SAMPER, J., MOREIRA, S., ALVARES, D. (2008) Model predictions of water chemistry for the future pit lake in As Pontes, A Coruña (Spain). 10th International Mine Water Association Congress.

SÁNCHEZ-PALENCIA, F.J., FERNÁNDEZ-POSSE, M.D., FERNÁNDEZ MANZANO, J., OREJAS, A., PÉREZ, L.C., SASTRE, I. (2000) Las Médulas (León), un paisaje cultural Patrimonio de la Humanidad. Trabajos de Prehistoria, 57, 195-208.

SANJURJO-SÁNCHEZ，J.; ALVES，C. Pollutant-Induced Decay of Building Materials. In Environmental Chemistry for a Sustainable World: Volume 2: Remediation of Air and Water Pollution; 
Lichtfouse, E.; Schwarzbauer, J.; Robert, D., Eds.; Springer Netherlands: Dordrecht, Netherlands, 2012; pp. 47-120. DOI:10.1007/978-94-007-2439-6_2

SCHROEDER, H. Sustainable Building with Earth; Springer International Publishing: Cham, Switzerland, 2016. DOI:10.1007/978-3-319-19491-2

SFGB-STONE Federation Great Britain. Natural Stone the oldest sustainable material, Publication Number SUS01/11. SFGB: Kent, UK, 2011.

SLEIMAN, M.; BAN-WEISS, G.; GILBERT, H. E.; FRANÇOIS, D.; BERDAHL, P.; KIRCHSTETTER, T. W.; DESTAILLATS, H.; LEVINSON, R. Soiling of building envelope surfaces and its effect on solar reflectance-Part I: Analysis of roofing product databases. Solar Energy Mater Solar Cells 2011, 953385-3399. DOI:10.1016/j.solmat.2011.08.002

SMITH FLETT, J. (1911) Petrology. In The Encyclopaedia Britannica: a dictionary of arts, sciences, literature and general information. Volume XXI, 11th Edition, University Press: Cambridge, England.

THOMAS, J.; DRÁBOVÁ, D. Wastes from the former uranium paint factory at Joachimstal (Jáchymov) used in dwellings. Environ Internat. 1993, 19:509-512. DOI:10.1016/0160-4120(93)90276-N

TISKATINE, R.; EDDEMANI, A.; GOURDO, L.; ABNAY, B.; IHLAL, A.; AHAROUNE, A.; BOUIRDEN, L. Experimental evaluation of thermomechanical performances of candidate rocks for use in high temperature thermal storage. App Energ. 2016, 171:243-255. DOI:10.1016/j.apenergy.2016.03.061

TREVISI, R.; RISICA, S.; D'ALESSANDRO, M.; PARADISO, D.; NUCCETELLI, C. Natural radioactivity in building materials in the European Union: a database and an estimate of radiological significance. J Environ Radioact. 2012, 105:11-20. DOI:10.1016/j. jenvrad.2011.10.001

TWIDALE, C. R., \& VIDAL ROMANÍ, J. R. (2005). Landforms and geology of granite terrains. Leiden: Balkema.

UGUR, I.; DEMIRDAG, S. Investigation of the relation between the specific heat capacity and material properties of some natural building and facing stones. Internat $\mathrm{J}$ Rock Mech Mining Sci. 2006, 43:831-835. DOI:10.1016/j. ijrmms.2005.12.003

Warheit, D. B.; Sayes, C. M.; Reed, K. L.; Swain, K. A. Health effects related to nanoparticle exposures: Environmental, health and safety considerations for assessing hazards and risks. Pharmacol Therapeut 2008, 120:35-42. DOI:10.1016/j.pharmthera.2008.07.001

Wylie, A.G.; Candela, P.A. Methodologies for Determining the Sources, Characteristics, Distribution, and Abundance of Asbestiform and Nonasbestiform Amphibole and Serpentine in Ambient Air and Water. J Toxicol Environ Health, Part B 2015, 18:1-42. DOI:10.1080/109 37404.2014.997945. 